\title{
Systematic review: systematization of information in accreditation processes for academic programs
}

\section{Revisión sistemática: sistematización de información en procesos de acreditación para programas académicos}

\author{
RIVERA-GUTIÉRREZ, Erika†** \& HIGUERA-ZIMBRÓN, Alejandro \\ Universidad Autónoma del Estado de México, Centro de Investigación en Arquitectura y Diseño, Mexico.
}

ID $1^{\text {st }}$ Author: Erika, Rivera-Gutiérrez / ORC ID: 0000-0001-6966-2721, Researcher ID Thomson: AAJ-7948-2020, CVU CONACYT ID: 247442

ID $1^{\text {st }}$ Co-atuhor: Alejandro, Higuera-Zimbrón / ORC ID: 0000-0002-7851-7531, Researcher ID Thomson: AAJ-75502020, CVU CONACYT ID: 226412

DOI: $10.35429 /$ JSEM.2021.23.8.19.28

Received July 15, 2021; Accepted December 30, 2021

\begin{abstract}
The research was designed to help resolve the absence of the systematization of information in the accreditation processes for academic programs in higher education institutions. In order to facilitate academic programs that are going to undergo evaluation processes to satisfy with the criteria, guidelines, and quality standards established by higher education accreditation organizations. A qualitative methodology was determined with a nonexperimental design and a descriptive approach, through a review of scientific literature, empirical references, supported by the systematic review method; a procedure was established to support the existence of the research problem by applying the Cochrane Manual of systematic reviews. It was proposed to develop a systematic review of the systematization of information in the accreditation processes for academic programs. Finally, a series of conclusions were presented.
\end{abstract}

Systematization of information, Process, accreditation, Evaluation of academic programs, Systematic review

\begin{abstract}
Resumen
El estudio fue diseñado para contribuir a resolver la ausencia de una sistematización de información en los procesos de evaluación para la acreditación de programas académicos en instituciones de educación superior, con el fin de facilitar a los programas académicos (PA) que van a someterse a procesos de evaluación cumplir con la guía de criterios, lineamientos y estándares de calidad establecidos por los organismos evaluadores. Para ello, se determinó una metodología de corte cualitativo con diseño no experimental y un enfoque descriptivo, mediante revisión de literatura, referentes empíricos, apoyada del método de revisión sistemática; se estableció un procedimiento para sustentar la existencia del problema de investigación aplicando el Manual Cochrane de revisiones sistemáticas (RS). Se desarrolló una RS de la sistematización de información en procesos de acreditación para PA; por último, se esbozaron las conclusiones del estudio.
\end{abstract}

Sistematización de información, Proceso, acreditación, Evaluación de programas académicos, Revisión sistemática

Citation: RIVERA-GUTIÉRREZ, Erika \& HIGUERA-ZIMBRÓN, Alejandro. Systematic review: systematization of information in accreditation processes for academic programs. Journal of Systems and Educational Management. 2021. 823:19-28.

*Correspondence to Author (Email: eriverag@ @uemex.mx)

$\dagger$ Researcher contributing as first Author. 


\section{Introduction}

As a result of the social dynamics currently being experienced around the world, higher education institutions have given the population access to inclusive quality education that contributes to the achievement of a better personal, professional and social life for citizens. In this sense, the accreditation of academic institutions and programmes (APs) has become a necessity to promote the improvement of the quality of education, through evaluation processes by nationally and internationally recognised accrediting bodies. However, higher education institutions (HEIs) face the absence of a systematisation of information in their evaluation processes for the accreditation of their APs, which would allow them to achieve quality assurance of these. Espí (2014) stresses the need to incorporate evaluation and accreditation processes in HEIs through management indicators, linking self-evaluation with institutional planning, helping to improve information management, planning, administration and monitoring, as well as ongoing self-evaluation, decision-making in HEIs, and the systematised management of their information under remote digital environments. Therefore, the purpose of this study focuses on analysing the scientific production regarding the systematisation of information in accreditation processes for AP with the aim that HEIs introduce new methods systematically in their evaluation processes in the framework of the establishment of basic standards or indicators by accrediting bodies through face-to-face, remote or hybrid systems.

In order to achieve this, a systematic literature review methodology was used to select and retrieve empirical and scientific evidence on aspects centred on the way in which institutions systematise information to carry out the evaluation processes of their academic programmes in order to achieve accreditation and thus move towards quality assurance. Studies were extracted according to specific selection criteria. As part of the findings, it stands out that several of the selected studies coincide in their results and make evident the need for HEIs to have a systematisation of information in their evaluation processes for the accreditation of their APs.
Among the conclusions, it is observed that HEIs have not given the required importance to the systematisation of information in the selfevaluation processes of their APs; thus, this review can serve as a guide for the work of the institutions in these processes in a systematic and continuous manner. It is also considered that it is necessary to go deeper into the subject and generate strategies that allow educational institutions to implement them, thus contributing to the quality assurance of their programmes.

\section{Development}

\section{Background}

As a result of today's rapid and immeasurable technological transformation, not only what and how things are done is changing, but also the information systems (IS) or the systematisation of information (IS) have been substantially transformed in various fields (economic, political, social, among others). In this sense, this has posed new challenges to education and consequently to higher education institutions. Hence, they must focus on generating or developing new educational models, academic relevance criteria, competences, continuous training processes, as well as various technological tools that contribute to the integration of the knowledge society and the technological era.

Echeverría et al. (2021) state that in the last 30 years, organisations of all types have become aware that information has become an intangible asset of great value. Consequently, decision-making areas at the managerial level are directly linked to the quality of the information they have. The educational environment is no exception considering that the information systems that an educational institution must have must be able to handle a wide range of data, where data can be stored, generated, created, implemented and processed. As a result, it is possible to have reliable information that effectively and efficiently enables the orientation of the entire community of the institution, particularly students, teachers and researchers, as well as for the evaluation of the APs that enables decision making in the generation of action plans both inside and outside the HEI. 
Barcos et al. (2018) point out that the systematisation of information for both HEIs and their academic programmes has become key to their planning, coordination and evaluation. They also highlight that:

Higher education is in a process of change to improve the quality of education and services and to adapt to the processes of evaluation, accreditation and convergence. Information technology, which has made extraordinary advances in recent times, must be incorporated into the university in an orderly and responsible manner, taking into account its dual nature as a consumer and producer of information. The university transmits knowledge, develops competences and modifies behaviour in all its members (students, teachers, non-teaching staff) and also in the community because through research and extension it contributes to social development. (p. 8)

For this reason, it is evident that the information with which an educational programme operates is diverse, considering that it is made up of data that must be systematised in these information systems, for example: a) student data: demographic, social, cultural, economic, environmental, students attended, new students, graduates, regular and irregular students, entry and exit profile characteristics, mobility, retention and drop-out rates, evaluations, statistics, pass and fail rates, laggards, academic trajectories, to mention but a few; b) teaching staff, research, extension, training, seniority, among others; c) curriculum and each of the learning unit programmes that comprise it; d) administrative data: budgets, costs, economic and financial prospects, material resources, material resources, seniority, among others; e) administrative data: budgets, costs, economic and financial prospects, material resources, seniority, among others: research, extension, training, seniority, among others; c) curriculum and each of the programmes of the learning units that comprise it; d) administrative: budgets, costs, economic and financial prospective, material resources, infrastructure, attendance records, etcetera. All information that is directly linked to the operation of the curriculum.
Consequently, it is important that the information systems within the educational institutions are part of the operation of the academic programmes offered, as well as the fact that they must adhere to the quality evaluation schemes from the administrative point of view as well as the academic performance of both the teacher and the student.

Also, Gonzalez-Longatt (2017), agrees with Barcos et al. (2018) that IS "have been configured as an important and required tool to support the decision-making process of organisations. From this perspective it should be absolutely clear that every organisation requires them, and demands them throughout its existence" (p. 10). Accordingly, Matias (2021) argues that information systems enable the collection, management and manipulation of a set of data that integrate the indispensable information for HEI managers to be able to make reliable and accurate decisions. He further highlights that:

Everyone involved in any kind of task in educational settings is aware that information is crucial to reach the proposed objectives. Therefore, the first impact is that Information Systems are a key tool and a prerequisite to support decision making and to manage everything that happens in it.

Improved access to information is recognised as an extremely useful ingredient for educational services and for the planning, diagnosis, operation and monitoring of plans and programmes; it also contributes to the evaluation of educational activities and of the results of academic and management intervention. (Matías, 2021, p. 8).

Therefore, there is a direct concordance with what is mentioned by the Consejo para la Acreditación de la Educación Superior, A.C. (COPAES) (2021, p. 8). (COPAES) (2021) and the Comités Interinstitucionales para la Evaluación de la Educación Superior, A.C. (CIEES) (2021). 
(CIEES) (2021), given the imminent need to generate effective and efficient information systems for educational institutions, or for each of their academic programmes; this is a consequence of the problems that have arisen in the assessment processes of the APs to achieve accreditation, caused by inefficient or incomplete management and information systems; or, others do not even have this type of system, where the information or data come from various unreliable sources, not giving certainty of validity and reliability to academic peers in the assessment processes.

\section{Theoretical Framework}

The theory underpinning the research problem refers to the systematisation of experiences promoted and disseminated by Jara (2016). This author defines it as a vital and unique process, which expresses an enormous wealth of elements and is therefore unprecedented and unrepeatable.

Also, Expósito and González (2017) mention that the systematisation of experiences:

It is a critical interpretation of one or several experiences that, from its ordering and reconstruction, discovers or makes explicit the logic of the process, the factors that have intervened in it, how they have been related to each other and why they have done so in that way. (p.1)

In other words, systematisation focuses on the reconstruction and analytical reflection of an experience, through which an event is interpreted in order to understand it; hence, it is possible to obtain knowledge, as well as to communicate it and contrast it with other experiences. As Expósito and González point out:

It allows us to contribute to an accumulation of knowledge generated from and for practice. In which, systematising or systematisation is to stop, look back, see where we have come from, what we have done, what mistakes we have made, how we correct them to guide the course, and then generate new knowledge, the product of criticism and selfcriticism, which is dialectics, to transform reality. (2017, p. 1)
Thus, the importance of incorporating the practice of systematisation in the educational environment, particularly in the accreditation of APs, is evident. Likewise, it is more relevant than ever that programme evaluation must have valid data on the process of teaching and learning, as well as to determine both strengths and weaknesses, and consequently seek to improve what this entails for the benefit of students.

In a study carried out by Semper (2020), the need to develop strategic planning for the accreditation processes of degree courses at the National University of La Plata is discussed. Emphasis is placed on the lack of permanent and systematic production of information on the dimensions for the accreditation processes of their degree courses, as well as the generation of strategies and training materials for these processes. In the conclusions, Semper highlights the need to generate guidelines to develop strategic planning for the accreditation processes of their degree programmes, unifying criteria, as well as an integral, systemic and permanent management policy for the improvement of the quality of their degree programmes.

Likewise, Ramos et al. (2020) point out that the incorporation of ISO standards into university management represents an efficient use of human, financial and academic resources, as well as the satisfaction of society. Where the success of accreditation processes is a function of control work, in such a way that academic evaluations are a key tool, so that academic auditing becomes a tool for this management. The study makes evident the need to include academic audits as an effective tool in the control of systematised processes, considering that they provide information to the university to improve its performance and the academic quality of its programmes. It concludes that accreditation as a process begins with selfevaluation and external evaluation, where the academic audit contributes to evaluation from a systemic perspective. 
For their part, Cevallos and Romero (2017) refer that quality is understood not only from the improvement of the vocational training system in terms of the results obtained (effectiveness), but also from the evaluation and quality of the vocational training system (efficiency). Therefore, quality must establish different indicators that provide different information on each element of the process. Therefore, evaluation is the instrument by means of which it is possible to assess the degree of quality of a process. These authors also argue that quality and evaluation should be treated jointly and in a related way in the educational field. In other words, the benchmarks of what is understood by quality in education in general, and in vocational training in particular, must be established. In addition to this, quality focuses on the fulfilment of a purpose in the shortest possible time and at the lowest possible cost, i.e. effective and efficient quality.

No less important is what Frades (2019) states, when he emphasises that evaluation must be a systematic and rigorous process of data collection, incorporated into the educational process from the beginning, so that continuous and significant information is available to know the situation, form value judgments regarding it and make the right decisions to continue the educational activity, improving it progressively. Cevallos and Romero (2017) also comment that evaluation must be carried out both in its internal dimension, oriented towards the quality of the education system itself, and in its external dimension.

To achieve this, it is necessary, as mentioned by De la Garza et al. (2015), to generate a culture of permanent and systematic evaluation that contributes to the management, assurance and control of the quality of higher education. This would allow institutions to be accountable to society and the state, and the latter to vouch to society for the quality of the service provided. Therefore, we agree with Buendía (2013) that we must move towards a model that re-evaluates these evaluation processes based on qualitative considerations that take into account the specific conditions of each case in terms of the experiences acquired from accredited educational programmes.
For this reason, it is necessary to carry out this study focused on the systematisation of information on the accreditation process for AP, which contributes to the improvement and ongoing assurance of quality in education.

Espí (2014) also points out that accreditation is a mechanism for publicly certifying the quality of programmes and institutions, based on the self-evaluation carried out by the institution's groups linked to the object of evaluation, followed by an external evaluation carried out by designated peers whose main function is to verify the objectivity of the evaluation. It is therefore defined as a process by which an educational institution or programme provides information about its activities in order to make public judgements about the value and educational quality of the institution or programme, based on standardised criteria.

Cardoso et al. (2009) argue that programme evaluation is a set of skills and abilities aimed at determining whether the services provided are necessary, whether they are used, whether they are sufficient, whether they are provided as planned, whether they help within a reasonable cost or even whether they cause undesirable effects. For that reason, the evaluation of AP should be seen as a systematic process that acts on the elements of the educational process in terms of its results, in order to provide the necessary information for decision-making on the evaluated object.

Jara (2016) describes systematisation as the critical interpretation of one or several experiences that, by ordering and reconstructing them, discovers or explains the logic of the process experienced in them. Thus, systematisation as an ordered, sequential and permanent process of reflection, which allows the practices and actors involved to be enriched, with the aim of creating knowledge through the experiences that occur in the intervention or in a social reality, as in the case of this study.

It is worth noting that the central problem of higher education has been the issue of educational quality, which is currently the focus of attention of specialists and actors involved in the processes of evaluation and accreditation, as well as of the bodies responsible for this activity. 
In this sense, it is evident that due to the generalised economic crisis resulting from the COVID-19 health contingency, there is a great concern throughout the world to allocate economic resources more efficiently, which has led to the search for evaluation systems in which there is greater participation of the state or the community in terms of control of expenditure and educational performance.

Hence, it should be noted that there is currently a trend away from traditional disciplinary evaluation towards approaches that place greater emphasis on understanding the reality of education in order to improve it. Furthermore, from the evaluation of elements or parts of the educational system in HEIs, there is a tendency to evaluate all its components (inputs, processes and outputs), including the environment of the system; because the qualities or behaviours of a social entity are being affected by unexpected risk factors. For all the above reasons, the following question was posed: Do HEIs have a systematisation of information for the accreditation processes of their APs, which allows them to achieve quality assurance of these?

\section{Systematic review}

Urra and Barría (2010) refer to the systematic review (SR) as a process to identify the core of a literature review of interest to the practice, searching for and extracting the most relevant according to criteria that have been evaluated and respected by others. Based on the above, SR can be understood as the process of developing a review of the literature of interest to the practice, which summarises and analyses the evidence for a specific question in an explicit and systematic way. Likewise, Ferreira et al. (2011) refer to the application of SR as a methodological approach for research in education, where it is possible to obtain up-to-date information on the topic being addressed.

Therefore, for this study, the systematic review was used as a method, where the Cochrane Handbook of Systematic Reviews was applied as an instrument that serves as a guide for researchers in the preparation of SR (CCI, 2012) under the General Method for Cochrane Reviews. To this end, taking as a reference both the outline of a Cochrane review protocol and the sections of a SR included in the manual, two formats were designed.
These allowed the information obtained from the extensive literature search to be stored and managed.

The first format (Record Sheet 1 (Annex 1)) was designed to organise the sources of information found in the first phase of the SR, while the second format (Record Sheet 2 (Annex 2)) was structured to store the data from the content analysis of the articles found on the systematisation of information on PA evaluation processes or PA accreditation processes. In addition, a checklist for data extraction was also considered, based on the aspects mentioned above.

\section{Procedure}

In order to achieve the purpose of this research, the Guide to the content of a protocol and a Cochrane review (CCI, 2012) was used as a reference instrument. According to this, the steps of the process for conducting the SR were determined, which were adapted from the guide, as well as those mentioned below:

1. Formulation of the problem: The need for SR was identified by means of a proposal, and the research question was defined. The concepts or variables involved in the research were determined. The question that arose for this review was: Do higher education institutions have a systematisation of information for the accreditation processes of their APs, which allows them to achieve quality assurance of these?

2. Location and selection of studies: Studies were identified on the basis of an extensive, unbiased literature search on systematisation of information on accreditation processes for evaluated APs. Here we considered the studies addressed in the research question, as well as the inclusion and exclusion criteria referring to language and time range. The following characteristics were taken into account: (a) research that proposed assessment or accreditation processes in AP, (b) belonging to higher education institutions, (c) studies conducted in English and Spanish language, (d) those that had not been conducted 10 years ago. 
Once the inclusion and exclusion criteria had been specified, a literature search was carried out in formal and informal sources. With regard to formal sources, specialised databases such as Google Scholar, Web of Science, Eric Data base and Thesaurus, ProQuest Central, Redalyc and Wilson Web were consulted, as well as journals specialising in specific topics of information systematisation, evaluation processes, accreditation and higher education. As informal sources, unpublished studies, discussion papers, proceedings, conference proceedings books, textbooks on the subject, doctoral theses or reports by prestigious researchers, scientific societies, working groups, among others, were considered.

3. Assessment of the quality of the studies: On the one hand, the studies were selected based on their quality assessment. This sought to assess the validity of the individual studies and certain design features for the interpretation of the results, to discover the reasons for the differences between the results of the studies and to provide sufficient information to judge their applicability. As Carrión et al. (2021) point out, data extraction also allows the reader to see how the research has been organised, as well as following each of the aforementioned stages very rigorously in order to provide truthful, accurate and reliable information that can be applied to future studies related to the systematisation of information in academic programmes.

On the other hand, the interpretation of the results depended on the validity of the studies included. The validity of a study refers to the ability to avoid systematic errors or biases through the correct design and conduct of the study. These errors were largely due to studies that appeared to be duplicates when they were classified and analysed, and were therefore discarded from those that had been selected. In addition, differences in the validity of the included studies helped to explain the variability of the results. In addition, we chose studies that considered the following points: (a) they were from higher education institutions, (b) based on AP, (c) that included evaluation or accreditation processes, (d) contemplated systematisation processes (e) written in Spanish and English, and (f) had references.

4. Data extraction: Once the studies included in the review had been defined, the data could be collected. Information that answered the research question was extracted from each study. Likewise, in order to organise the sources of information found, we used Record Sheet 1 , which allowed us to store and classify the sources located from the extensive literature search, considering the inclusion criteria described above, and proceeded to synthesise the results.

5. Analysis and presentation of the results: The analysis contemplated the organisation, categorisation and combination of the information data in order to provide a clear and direct answer to the question posed. As well as the content analysis of the selected sources of information, which was carried out with the Registration Form 2. The results of the study were presented according to the structure of Urra and Barría (2010).

6. Development of a proposal: Once the different articles on the systematisation of information on the assessment or accreditation processes of APs had been reviewed, the systematisation of information for AP accreditation processes was characterised.

\section{Conclusions}

In summary, the research problem to be carried out in the absence of the systematisation of information in evaluation processes for the accreditation of APs, which contribute to their quality assurance, was presented. As well as the main components that make up the research design, based on a theoretical-empirical basis with the aim of guiding the development of the research; in addition to the methodological approach that guided the object of this study, in order to answer the question posed and fulfil the purpose of the same. 
The second phase of the project was oriented towards the application of the methodological design, where data collection and analysis were carried out, and the findings were contrasted with the review of the scientific literature. It should be noted that the originality of the research is due to the fact that to date no studies have been published on the subject, in this sense it generates a contribution of innovation in the field of education.

In view of the above, on the one hand, it is important to emphasise that accreditation is not autonomous; it is accompanied by other policy instruments and dynamics of the Higher Education system itself, which contribute to the improvement of quality in education; not all institutions have the same motivations and circumstances to incorporate their APs in accreditation processes under normal or contingency conditions, so that these and their impact are different depending on the context and type of institution in question. Currently, a special concern of HEIs is focused on the analysis of these processes in relation to improvements in teaching and learning as a central point, where institutions hope to generate significant changes that will prevent students from falling behind and dropping out of school. Thus, accreditation should be seen by HEIs as a process of permanent evaluation and improvement, integrating a new strategic conception of planning and management of faceto-face, blended or remote higher education, in accordance with the normal conditions, contingencies or risks of the national context.

On the other hand, the research showed that most HEIs do not systematise their information, which has a direct impact on the quality assurance of the APs as they do not document not only the information but also all the processes linked to academic matters, tutoring, management, liaison and research, which was contrasted with the results of the studies consulted. Consequently, the lack of systematisation of information supported by information and communication technologies, both in contingency and normal conditions, leads to a lack of reliable and timely information, making it impossible to carry out an adequate evaluation process for accreditation purposes.
Hence, the systematisation of information on accreditation processes for both APs and HEIs becomes necessary not only in contexts such as the one currently being experienced by COVID-19, but also on a permanent basis as a result of the digitalisation of education, moving towards systematisation, connectivity, digital information, digital access, if not of all services then of most of them, as well as the application of Web 4.0.

This is in addition to what Suárez et al. (2021) point out, where the absence of a culture of evaluation in HEIs, as well as the unstable or scarce university training systems do not allow the needs detected to be met. Moreover, if we add that universities do not have the necessary financial resources to hire teachers, let alone for professional development and research programmes, as a consequence, the educational quality of academic programmes is being directly affected, as well as the training of human resources for the new generations.

No less important, it highlights the need to increase educational activities through the use of ICT, in relation to teaching, research, extension, dissemination and community service, in accordance with the generation of policies for the use focused on meeting the goals of Education 2030; consequently, the integration of the comprehensive systematisation of effective and efficient information is recommended as indispensable, contributing to the goals set by this type of organisation.

Finally, the prospective on the subject that was addressed allows us to glimpse the development of other studies that link systematic reviews focused on evaluating the impact of information systematisation in educational institutions at any level of studies; or also that the systematisation of information can be visualised in other educational products, with different characteristics depending on what has been systematised, what it has been systematised for and how the learning from this process is going to be applied. 


\section{References}

Alfaro, I., \& Horna, M. V. (2019). Competitividad en la exportación de la agroindustria a través de una agencia de aduanas, una revisión sistemática de la literatura científica de los últimos 10 años. Repositorio de la Universidad Privada del Norte. Recuperado de https://hdl.handle.net/11537/26109

Barcos, S. J., Denda, E., Paolini, N., Diego Álvarez, G. D., \& Di Giovamn, B. N. (2018). Aprendiendo el proceso administrativo y algo más. La Plata: Editorial Dei Genitrix, La Plata.

Buendía, E. A. (2013). Genealogía de la evaluación y acreditación de instituciones en México. Perfiles Educativos, vol. XXXV. Instituto de Investigaciones sobre la Universidad y la Educación. Distrito Federal, México. Recuperado de http://www.redalyc.org/articulo.ao?id=1322996 0003

CCI (Centro Cochrane Iberoamericano) (2012). Manual Cochrane de Revisiones Sistemáticas de Intervenciones, versión 5.1.0 [actualizada en marzo de 2011] [Internet]. Barcelona: Centro Cochrane Iberoamericano. Recuperado

de: http://www.cochrane.es/?q=es/node/269.

Cardoso, E., Ramos, J. \& Tejeida, R. (2009). Evaluación de los programas educativos desde la perspectiva de los sistemas suaves: Propuesta metodológica. Revista Universidad EAFIT, 45(155), 30-44. Costa Rica: Universidad

Carrión, G. R. S. (2021). Merchandising visual como efecto persuasivo en el comportamiento de compra del consumidor. Revisión sistemática y metaanálisis. Repositorio de la Universidad César Vallejo. Lima, Perú.

Cevallos, S. N. \& Romero-Sandoval, A. (2017). Mejoramiento de la calidad de la educación superior desde la comparación de estándares. INNOVA Research Journal,2(7), 13-33.

https://doi.org/10.33890/innova.v2.n7.2017.223

CIEES (Comités Interinstitucionales para la Evaluación de la Educación Superior, A.C.) (2021). Estatutos. Ciudad de México, México. Recuperado de https://www.ciees.edu.mx/
COPAES (Consejo para la Acreditación de la Educación Superior, A.C. (2021). Gaceta COPAES. Ciudad de México, México. Recuperado de https://www.copaes.org/news.html

De la Garza M., E. I., et. al (2015) La evaluación y acreditación de los programas académicos y su impacto desde la percepción estudiantil (The Assessment and Accreditation of Academic Programs and Their Impact From the Student Perception). Revista Internacional Administración \& Finanzas 8.2, 55-65. Recuperado http://papers.ssrn.com/sol3/papers.cfm?abstra ct_id=2500517

Echeverría, S. B. \& Martínez, C. P. (2018). Revolución 4.0, competencias, educación y orientación. Revista Digital de Investigación en Docencia Universitaria, 12(2), 4-34. doi: http://dx.doi.org/10.19083/ridu.2018.831

Espí, L. N. (2014). Evaluación y acreditación: saberes, pertinencia, expectativas (curso 13). Cuba: Editorial Universitaria. Recuperado de http://www.ebrary.com

Expósito, U. D. \& González, V. J. A. (2017). Sistematización de experiencias como método de investigación. Gaceta Médica Espirituana, 19(2), 10-16. Recuperado en 11 de octubre de 2021, de http://scielo.sld.cu/scielo.php?script=sci_artte $\mathrm{xt} \&$ pid=S1608$89212017000200003 \& \operatorname{lng}=$ es \&tlng=es.

Frades, S. E. (2019). La supervisión educativa como función principal de la Inspección. Características y propósitos. Aula, 25, 27-58. https://doi.org/10.14201/aula2019252758

Gonzalez-Longatt, F. M. (2017). Introducción a los Sistemas de Información: Fundamentos. https://www.uv.mx/personal/artulopez/files/20 12/08/FundamentosSistemasInformacion.pdf

Frades, S. E. (2019). La supervisión educativa como función principal de la Inspección. Características y propósitos. Aula, 25, 27-58. https://doi.org/10.14201/aula2019252758 
Jara, H. O. (2016). La sistematización de experiencias y las corrientes del pensamiento innovadoras histórica aproximación latinoamericano-una. Piragua, (23). Recuperado de http://www.cepalforja.org/sistem/sistem_old/os car_jara-

sistematizacion_y_corrientes_innovadoras.pdf

Ramos, C. G., González, S. A., Hernández, N. A., Prado, G. G., Garay, C. M., \& Scull, M. M. (2020). La auditoría académica como herramienta para evaluar la calidad y apoyar la acreditación institucional. Educación Médica Superior, 34(2). Recuperado de http://ems.sld.cu/index.php/ems/article/view/ 1903/1070

Semper, M. (2020). La planificación estratégica de los procesos de acreditación de las carreras de grado de la UNLP como política permanente de mejoramiento. Tesis. Recuperado de http://sedici.unlp.edu.ar/handle/10915/115641

Suárez, N., Requeiro, R., Urosa, Belén M., \& Cáceres, M. L. (2021). Evaluación de la docencia universitaria. Tendencias y tensiones fundamentales. Formación universitaria, 14(3), 37-46. https://dx.doi.org/10.4067/S071850062021000300037

UNESCO (2019) Guidelines on the development of open educational resourse policies (Directrices para la elaboración de políticas de recursos educativos abiertos) France: UNESCO.

Urra, M. E., \& Barría, P. R. M. (2010) Systematic Review and its Relationship with Evidence-Based Practice in Health. Revista Latino-Americana de Enfermagem [online], v. 18, n. 4 Disponible en: <https://doi.org/10.1590/S010411692010000400023>. Epub 27 Set 2010. ISSN 1518-8345. https://doi.org/10.1590/S010411692010000400023. 